\title{
Refugees and the Prospects for Peace and Development in Central America
}

\author{
Brian Egan and Alan Simmons
}

\section{Introduction}

On the morning of January 20, 1993 a caravan of more than seventy-five buses wound its way out of the Mexican city of Comitán towards the nearby Guatemalan border. On board were close to 2,500 Guatemalan men, women and children, most of whom had spent the last decade in refugee camps scattered through southern Mexico. Many of the children were too young to have any memory of the land they were returning to. Others, having been born in the camps, had never set foot in Guatemala. Together, children, parents and grandparents were taking part in the first large scale return of Guatemalan refugees from Mexico. At the border and along the highway which traverses Guatemala's lush, mountainous, western highland, large crowds gathered to welcome the returning refugees. In Guatemala City, a large rally was organized to celebrate the return. Refugee leaders described the process as a positive step forward in the struggle for peace, justice and democracy in Guatemala. They stressed that the return was a voluntary, collectively organized effort rather than a state imposed repatriation.

The Guatemalan return was preceded by similar repatriations to Nicaragua and El Salvador-the other two Central American nations gripped by war in the 1980s. Between 1.7 million and 2.7 million people were uprooted in these countries during the first half of the 1980s. Although the numbers are disputed, between 860,000 and 1.7 million fled into exile-with 300,000 to 600,000 seeking refuge in neighbour-

\footnotetext{
Alan Simmons is a professor of sociology at York University. Brian Egan is a graduate student in the Faculty of Environmental Studies, York University.
}

ing countries (Central America or Mexico) and 675,000 to 1.16 million eventually making their way to the United States or Canada. Close to one million more became internally displaced, i.e., they fled their home due to war or violence but remained within their own country (Simmons 1993, 291).

In recent years this outflow of people has begun to reverse, with the Guatemalan return representing only the latest wave of refugee repatriation. Since the late 1980s, tens of thousands of Nicaraguans and Salvadoreans have also returned to their homelands and begun the process of rebuilding their lives. In addition, many people who were displaced within their own countries by violence and war have begun to return to their home communities or to resettle in areas nearby.

Central America finds itself at a critical juncture. The current return of refugees and displaced peoples reflects a transition from a period when the region was dominated by war to one where peace and reconciliation have taken hold. The transition is uncertain and fragile, however, with many of the conditions which spawned the conflict remaining unaltered. In addition, the refugees themselves have changed as a result of their flight, long periods in exile, and experience gained from dealing with international organizations while abroad. How will the returning refugees fare, given such circumstances? What are the prospects for peace and development not only for the returning refugees but also for the many more Central Americans who were displaced or traumatized by the civil conflict of the 1980s?

\section{Crisis, Conflict and Flight}

The origins of the current Central American crisis can be found in the history of colonization and develop- ment of the region, in particular since the second half of the nineteenth century, when the region was incorporated into the world economy as an exporter of primary agricultural commodities. At that time, local elites began to expropriate lands held by Indian communities and small farmers in order to take advantage of a growing international demand for tropical products such as coffee and bananas. Most of the region's prime agricultural land was soon concentrated in the hands of a few (North et al. 1990, 58). The former owners of these lands were displaced to small and marginal plots of land which were inadequate to meet their subsistence needs. Others became landless migrant labourers. A dual system of agricultural production was established -with large farms producing for export and small farms producing for local consumption-a system which persists to this day.

The imposition of this new economic order generated considerable popular resistance, including numerous peasant rebellions throughout the period of land expropriation. In order to protect their new assets, local landholding elites depended on an increasingly organized and efficient military apparatus; peasant rebellions were ruthlessly quashed. In 1932, one such rebellion in El Salvador was crushed with the resultant loss of ten thousand to thirty thousand lives, mostly peasants and indigenous peoples. Through the process of land expropriation, the land-owning elite and the military became dominant and interdependent centres of power throughout Central America .

The more immediate roots of the Central American crisis stem from the postwar period. From the mid 1950s to the mid 1970s, Central America enjoyed a period of rapid economic 
growth, led by a "modernization" of the industrial and agro-export sectors. The agro-export sector grew rapidly, becoming increasingly diversified. Few of the benefits of this agricultural production, however, "trickled down" to the poor. In fact, in rural areas the gap between rich and poor grew as more small farmers and indigenous communities were dispossessed of their lands. In addition, the new export commodities (e.g., beef, cotton and sugar) were capital-intensive rather than labour-intensive. This reduced opportunities for employment, and the contradiction between an increasing rural labour force and declining employment in the agro-export sector became more acute. To make matters worse, the focus on production of export crops during this period created a shortfall of food staples (such as corn and beans) upon which the poor depended. Formerly self-sufficient in these staples, several Central American nations became importers of corn and beans (Torres-Rivas 1989, 29).

Through a policy of import substitution, a focus on national and regional (i.e., Central American) markets, and with increased foreign investment, industrial production also expanded rapidly during the postwar period, but with similar results for the poor. As this production was capital-intensive and geared toward the elite and middle classes, little new employment was created and most of the new products were beyond the reach of the poor (North et al. 1990, 30).

A series of shocks from the world economy during the 1970 s sent the vulnerable Central American economies into decline and crisis. The dramatic rise in oil prices in the early part of the decade sent interest rates soaring and triggered a round of high inflation. The poor were hardest hit as prices for basic foodstuffs increased beyond the reach of many. Strongly dependent on the export of primary agricultural commodities, the Central American economies were also hit hard by the worldwide recession which began in the mid 1970s. Prices and demand for these export com- modities went into decline. Also dependent on the import of machinery, petroleum, pesticides and basic food staples, the decline of export earnings led to acute balance of payment crises for most Central American nations. The private sector and state response to these crises was to cut employment, wages and social services which served to increase existing inequalities (ibid, 31).

While the economic system underwent dramatic change during the postwar period, the system of oligarchic domination of power remained largely intact. In response to worsening economic conditions, increasing disparity and raised expectations, a variety of popular organizations in rural and urban areas mobilized to press for economic justice-access to work and land-and for reform of the outdated system of political domination. Demands for democratization of the political process grew. While this mobilization was overwhelmingly reformist and non-violent, the states' responses were not (Torres-Rivas 1989, 27). Where popular demands were met by violent repression, such as in El Salvador, Nicaragua and Guatemala, revolutionary movements were spawned or strengthened. By the late 1970 s guerilla movements in each of these countries had grown to such an extent that they were able to seriously challenge military authority. By the early 1980 s open warfare broke out in Guatemala, El Salvador and Nicaragua.

In Guatemala, the military responded to small-scale guerilla actions in the western highlands and adjacent lowland areas with a massive and brutal counter-insurgency campaign. These predominately Mayan areas were devastated (Carmack 1988). In urban areas, death squads targeted students, unions and popular organizations. By the time the worst of the conflict had passed in 1984 more than four hundred villages had been razed, fifty thousand to one hundred thousand civilians had been killed either by the army or by death squads, and another thirty-five thousand had "disappeared" (USCR 1993, 4). Between 260,000 and 615,000 Guatemalans were forced to flee their communities, the majority becoming internally displaced to urban areas or remote jungle and mountainous areas. Between

Table 1: Refugees and Displaced Persons from and in Central America (Circa 1987)

\begin{tabular}{|c|c|c|c|c|}
\hline $\begin{array}{l}\text { Country of } \\
\text { Asylum }\end{array}$ & Salvadorians & Guatemalans & $\begin{array}{l}y- \\
\text { Nicaraguans }\end{array}$ & Totals \\
\hline United States & $\begin{array}{r}500,000 \\
\text { to } 850,000\end{array}$ & $\begin{array}{r}100,000 \\
\text { to } 200,000\end{array}$ & $\begin{array}{r}40,000 \\
\text { to } 80,000\end{array}$ & $\begin{array}{r}640,000 \\
\text { to } 1,130,000\end{array}$ \\
\hline Mexico & $\begin{array}{r}120,000 \\
\text { to } 250,000\end{array}$ & $\begin{array}{r}45,000 \\
\text { to } 150,000\end{array}$ & N/A & $\begin{array}{r}165,000 \\
\text { to } 400,000\end{array}$ \\
\hline Canada & 22,283 & 7,326 & 7,081 & 36,690 \\
\hline Central America & 51,700 & 7,700 & $\begin{array}{r}67,700 \\
\text { to } 163,700\end{array}$ & $\begin{array}{r}127,100 \\
\text { to } 223,100\end{array}$ \\
\hline Total refugees & $\begin{array}{r}585,983 \\
\text { to } 1,065,983\end{array}$ & $\begin{array}{r}160,026 \\
\text { to } 365,026\end{array}$ & $\begin{array}{r}114,781 \\
\text { to } 250,781\end{array}$ & $\begin{array}{r}860,790 \\
\text { to } 1,681,790\end{array}$ \\
\hline Total displaced & 500,000 & $\begin{array}{r}100,000 \\
\text { to } 250,000\end{array}$ & 250,000 & $\begin{array}{r}850,000 \\
\text { to } 1,000,000\end{array}$ \\
\hline
\end{tabular}

Source: Estimates for Central Americans Refugees in the United States, Mexico and neighboring countries in their own region from North and CAPA, Between War and Peace in Central America, Table VII. Estimates for Central American Refugees in Canada from Employment and Immigration Canada.

Notes: Refugees are defined as emigrants (living abroad) who have claimed or wish to claim political asylum. Displaced persons are those who have fled their homes due to war or violence, but who remain in their own countries. 
160,000 and 365,000 fled into exile, mostly to Mexico, but smaller numbers also went to Honduras and Belize. Eventually, some 45,000 settled in refugee camps in southern Mexico with as many as twice that number dispersed through Mexico (ibid, 6). Others made their way to the United States, Canada or Europe (see Table 1).

In El Salvador the reasons for refugee flight were similar. During the late 1970 s popular sector organizations were pressing for social change. In the face of state repression, opposition groups united to form a potent revolutionary force-divided into a political wing (the Democratic Revolutionary Front or FDR) and a military wing (the Farabundo Marti Liberation Front or FMLN). Repression of the political opposition drove many activists into the ranks of the FMLN. Armed conflict increased through the early 1980 s and persisted until the end of the decade.

El Salvador generated more refugees during the 1970s and 1980s than any other Central American nation. An estimated 25 percent of the population was uprooted by the conflict. A pproximately half a million were displaced within the country, most fleeing to the capital city, San Salvador, the population of which tripled over the decade of conflict. Over fifty thousand fled to adjoining countries, mainly Honduras. Well over half a million more fled north into Mexico, the United States, Canada and Europe (see Table 1).

In Nicaragua refugee flight began in 1982, three years after the triumph of the Sandinista revolution and shortly after the start of the resistance campaign waged by counter-revolutionary forces or "Contras." During the civil war 260,000 to 500,000 Nicaraguans became refugees or were internally displaced (see Table 1). Two distinct groups formed the bulk of Nicaraguan refugees generated during this period-mestizos (people of mixed ancestry) from the central highlands and indigenous peoples from the Caribbean lowlands in the northwest.

The displacement of indigenous peoples (Miskitos, Sumus and Ramas) began in the early 1980 s shortly after the Contras became active in the area. In response, the Sandinistas moved some 8,500 indigenous people inland, away from the Honduras border to a resettlement site called Tasba Pri ("Free Land"). The resettlement was officially justified by the Sandinistas as a way to protect the indigenous population in the area from attacks by the Contras launched from Honduras. However, the indigenous population saw the move as an attempt to subjugate local authority and disrupt their affairs. The resettlement exacerbated the long standing mistrust between the indigenous people and the central government of Nicaragua (North et al. 1990, 142).

Over the next few years, fifteen thousand to twenty thousand indigenous people fled to the Atlantic coast region of Honduras to avoid the Sandinista resettlement plans (Ortega et al. 1991, 20), while others joined the Contras. In 1985 the Sandinista government reversed its stand and allowed the resettled people to return to their original communities. In addition, after lengthy consultation, the government made significant concessions to the indigenous groups, granting them considerable autonomy. As a result of these actions, many of those who sought refuge in Honduras returned to their communities by the late 1980s (North et al. 1990, 142).

Far more numerous than those of indigenous origin, mestizo refugees fled into southern Honduras and northern Costa Rica from zones of conflict in adjacent parts of Nicaragua. The number of refugees flowing into Honduras and Costa Rica increased rapidly after 1983 as U.S. funding for the Contras increased. The situation of these Nicaraguan refugees is complicated by the fact that some of them were involved with the Contras, either as voluntary or involuntary combatants, or were family members of combatants. Of the approximately thirteen thousand mestizo refugees in Honduras (ibid, 147), most were campesinos (peasants) from northern rural areas. Those that fled to Costa Rica came from rural and urban areas in the south. In comparison to those who fled to Honduras, relatively few settled in camps-up to 65 percent settled in urban areas. Many who fled to Costa Rica claiming political persecution were in fact simply seeking to improve their economic status or to avoid the draft. Estimates of the number of Nicaraguans who fled to Costa Rica vary from twenty thousand registered refugees to two hundred thousand unofficial refugees (Ortega and Acevedo 1991. 20).

\section{Reception and Life in Exile}

The reception accorded by the various host governments and people to Central Americans fleeing their homelands ranged from tolerance to outright hostility, often reflecting the ideological and political goals of the receiving state or its allies. Salvadorean refugees fleeing into Honduras faced the most difficult conditions. On at least two separate occasions, groups of Salvadorean refugees trying to cross into Honduras were attacked and killed by a combination of Salvado. rean and Honduran armed forces. Once in Honduras, Salvadoreans were obliged to live in restrictive camps run by the Honduran military. Conditions in the camps were difficult-there was little security and the refugees were not permitted to work. On several occasions Salvadorean forces entered the camps and abducted or killed refugees and aid workers (North et al. 1990, 135).

Guatemalan refugees fleeing into Mexico faced similar difficulties. Most of the refugees made their way to the adjacent Mexican state of Chiapas, where they were met by a largely sym. pathetic local population but a hostile Mexican army. The army initially forced many refugees back into Guatemala. However, pressure by Mexican organizations, including the Catholic church in Chiapas, forced the government to allow refugee camps to be established along the Mexico/ Guatemala frontier. Cross-border raids by the Guatemalan military were common during this early period. Sharing a similar indigenous back 
ground with the local population, many refugees integrated successfully into local communities in Chiapas. Beginning in 1984, the Mexican government moved close to twenty thousand of the refugees to camps in the adjacent states of Campeche and Quintana Roo, ostensibly to protect them from raids carried out by the Guatemalan military (USCR 1993, 5). In Campeche and Quintana Roo the refugees were more isolated and subject to different cultural influences. For example, in the camps in Quintana Roo many of the refugee youths found work in Cancun or other major tourist centres nearby (see the paper by Linda
Costa Rica represented only a small fraction of the number of Nicaraguans, the Costa Rican government took various measures to discredit and discourage Salvadoreans who sought asylum in that country (North et al. 1990, 147).

The Contras had easy access to the Nicaraguan refugee camps in Honduras and exerted strong political and ideological control over the refugees. Because the camps provided them with recruits, the Contras tried to prevent Nicaraguan refugees from repatriating by controlling the media, and by creating a system of mistrust in the camps. For example, anyone who listened to the Voice of Nicaragua, the

\section{Few hard facts are available on Central Americans in Canada, but the general impression is that they have had greater difficulty than other immigrants and refugees. ... It may also be due to the fact that in Canada employment requires capacity in English or French (unlike the southwest United States where, for many jobs, Spanish is an asset).}

Geggie in this issue). In general, the Guatemalan refugees in Mexico enjoyed a certain amount of freedom to travel and work, and provided an important source of labour for small and large farmers in the region. It should be noted that these rights to work and travel were limited. Pay was very low and the Mexican government did suspend travel and work privileges periodically. However, the Mexican government did not welcome the presence of the refugees and exerted considerable pressure for their repatriation.

Reflecting political and ideological interests, the reception of Nicaraguan refugees in Costa Rica and Honduras differed considerably from that of Salvadorean refugees in these countries. Nicaraguans who fled into Honduras were not persecuted. Indeed, Nicaraguan indigenous refugees who arrived in Honduras before 1985 were often given land and mestizo refugees were free to travel and work within the country. Researchers have noted that a similar double standard was applied to Nicaraguan and Salvadorean refugees in Costa Rica. Although the number of Salvadorean refugees in official radio station of the Nicaraguan government, or who refused to identify themselves as a victim of the Sandinista government was suspected of being a Sandinista sympathizer (Ortega 1991, 30).

Many refugees from Central America fled the region entirely. Estimates suggest that 60 percent or more of the total number of refugees generated during this period fled to North America (see Table 1). Of these, the vast majority, between 640,000 and 1.1 million, went to the United States. Smaller but significant numbersaround thirty-six thousand by 1987also fled to Canada. U.S. figures show a particularly broad range, since most of the migrants entered the United States by land across the Mexican border without any documentation. Many of those who went to Canada arrived as visitors and then claimed refugee status after they were in the country. By far the largest movement to the United States and Canada was from $\mathrm{El}$ Salvador.

Many Nicaraguans also went to North America. Reflecting their strong ties to home culture and land, Guatemalan refugees were far more likely to stay in Mexico, although many also went further north.

Reception conditions in North America varied depending on country of origin, country of destination and period of arrival. Nicaraguan exiles (most of whom were opposed to the Sandinistas) were generally welcomed in the United States as "defenders of freedom," hence their conditions of arrival were relatively good in that country. A small number of Nicaraguan refugees fled further north to Canada. In contrast to the Nicaraguans, Salvadoreans were more often viewed as unwelcome dissidents in the United States. Their conditions were more precarious and they were more likely to move to Canada, where they had a high probability of being accepted as refugees. Tougher U.S. legislation, enacted in 1986, limited the number of undocumented migrants, which led to a corresponding increase in the number of Salvadorean refugee claimants in Canada (Simmons 1993, 301). While Canada has in general accepted claims for asylum originating both in Central America and from claimants who came on their own to Canada, there have been notable tragic incidents in which Canadian officials were too slow in responding to requests for refugee status from individuals facing death threats in the region (Whittaker 1987).

Gradually, information is beginning to emerge on the integration of Central American refugees in North America. Salvadoreans seem almost indistinguishable from Mexicans in their integration into the informal employment and low wage manufacturing sectors of the southwest United States (Fernandez et al. 1989). Integration among Guatemalan refugees seems to be following a similar path, although at a slower pace due perhaps to their greater cultural dislocation. Few hard facts are available on Central Americans in Canada, but the general impression is that they have had greater difficulty than other immigrants and refugees. This difficulty may be due in part to the fact that many arrived at the time of a national reces- 
sion and structural adjustment associated with high unemployment. It may also be due to the fact that in Canada employment requires capacity in English or French (unlike the southwest United States where, for many jobs, Spanish is an asset). How these diverse patterns of reception will affect the desire of refugees to return home in the future is unknown.

\section{Return and Reintegration}

On August 8, 1987 the presidents of Guatemala, Honduras, El Salvador, Nicaragua and Costa Rica signed Esquipulas II, a regional peace accord which linked peace and development efforts in the region with the resolution of the refugee crisis. In 1988, in response to a proposal from the Central American presidents, the United Nations began to organize the first meeting of the International Conference on Central American Refugees (CIREFCA). Out of the first CIREFCA meeting, held in Guatemala in May 1989, came a Plan of Action which helped establish conditions for the return of refugees throughout the region. Among other conditions, the Plan committed governments in the region to respect the rights of refugees and to recognize the legitimate role of nongovernmental organizations (NGOs) (Weiss Fagen 1993, 32).

While Esquipulas II and the CIREFCA Plan of Action helped form the institutional framework in which large scale repatriation could occur, other factors were often of greater importance. For example, the signing of the peace accord and the creation of CIREFCA seemed to have little impact on the rate of repatriation of Nicaraguan refugees. In the Nicaraguan case, two other events-the Nicaraguan election of 1990 and the series of agreements reached between the Sandinista government and the indigenous population-were of much greater importance.

A series of cease fire agreements and discussions over autonomy from 1984 to 1988 between the Sandinistas and displaced indigenous groups paved the way for the repatriation of these peoples. By 1988 most had returned to their areas of origin, including those who had been resettled in Tasba Pri, and had begun to rebuild their communities (Ortega 1991, 31).

The return of Nicaraguan mestizo refugees from Honduras and Costa Rica remained at a low level until the defeat of the Sandinistas in the 1990 election, following which the Sandinistas signed a peace agreement with the Contras. A massive repatriation of Nicaraguans from Honduras and Costa Rica followed. Over twentyfive thousand Nicaraguans repatriated in the last six months of 1990 alone (Ortega and Acevedo 1991, 37). By January 1993 a total of 71,500 had returned (Weiss Fagen 1993, 33). Many of those repatriating were Contra combatants who had to be disarmed-under the disarmament program close to twenty thousand turned in arms. Most of the internally displaced have also returned to their areas of origin.

The reintegration process in Nicaragua has been complicated by the fact that the return brought Nicaraguans from both sides of the conflict together in one community. In some areas, despite a decade of bitter conflict, the two sides have integrated peacefully. In other areas, especially where land is poor and other resources scarce, bitter feelings remain and there is intense competition for land and other economic resources. As a result, armed conflict has resurfaced in some areas.

In El Salvador the process of return took a much different route, beginning with the mass return of internally displaced people back to their regions of origin. The first such return was to the town of Tenancingo which had been destroyed by fighting and abandoned in 1984. This major return was facilitated by the Catholic church and a number of operational agencies it created. Following this example, grassroots organizations and the displaced organized several other mass returns in 1986 and 1987. In turn, these internal returns catalyzed refugees in the Honduran camps to organize for their own mass repatriation. By early 1990 virtually all the refugees in the Honduran camps had repatriated (Weiss Fagen et al. 1991, 144).

Many of the mass returns, both from within El Salvador and Honduras, were to zones of conflict controlled by the FMLN. Suspecting that these communities of returnees would become bases of support for the guerilla forces, the Salvadorean military made efforts to disrupt the returns, particularly for those returning from Honduras. The church played a crucial facilitating role by urging the military to allow the returns. The refugees also proved capable of mustering significant national and international support (ibid, 158).

Guatemalan refugees began returning from Mexico as early as 1984 under a government sponsored repatriation program. By December of 1990 a little over six thousand refugees had returned under this program. Most refugees did not partake of the government plan, however, largely due to uncertain political and economic conditions within Guatemala (AVANCSO 1992, 54). At the same time, the leadership of the refugees in Mexico (the Permanent Commissions or (CPP), had begun planning for a mass return once conditions in Guatemala improved and had begun negotiations with the Guatemalan government.

In October 1992, the Guatemalan government and the CCPP reached an agreement and signed an accord which recognized certain basic rights of the returnees.

Although political and economic conditions within Guatemala remained uncertain, the first group of refugees returned in January 1993. This group settled in the Ixcan, in the remote northern corner of the department of Quiche, an area which experienced some of the worst violence of the early 1980s and which produced many of the refugees who fled to Mexico. By early 1994 several thousand more refugees had returned to this same area, which remains a zone of active conflict between the army and guerilla forces. Like the Salvadoreans, the Guatemalan refugees are highly organized and have drawn significant support from Guatemalan and international NGOs. 


\section{Challenges: Toward an Agenda for Action}

Violence has diminished in the region as a whole but persists to some degree in many areas. Despite the end of the civil war in El Salvador, scattered " disappearances" and assassinations of the political opposition continue. In Nicaragua only a small contingent of Contra forces remains active, but the former Contra leadership and its allies abroad continue to threaten remobilization.

In Guatemala, military violence against indigenous communities has subsided, but the military remains pervasive throughout society. This is especially true in the countryside where civil patrols are omnipresent and low level conflict is ongoing in remote areas, making it perilous and risky for many refugees to return. In fact, Guatemala continues to generate new refugees, albeit in smaller numbers, even as other exiles are returning.

Another continuing challenge for the return arises from the fact that Central America, excluding Costa Rica, is one of the poorest regions in the Americas. The development challenge in the region is evident in the figures shown in Table 2.
Incomes in the poorest countries of the region are in the range of US $\$ 1,100$ per year in El Salvador and less in the other countries. Not only are incomes very low, but income growth over the twenty-five year period between 1965 and 1990 was either extremely low (less than 1 percent per year in Guatemala and Honduras) or negative (in the case of El Salvador and Nicaragua), reflecting the violence and economic disruption of civil war. Poor health and sanitation contribute to the high infant mortality rates in Guatemala, Honduras, Nicaragua and El Salvador that are double or triple those in Costa Rica and seven or eight times higher than those in the United States and Canada (see Table 2). There are relatively few doctors in the poorest countries of Central America, and high proportions of the adult population are illiterate; more than half of adult women in the case of Guatemala. While accurate information on income distribution and land tenure is hard to come by, it is widely acknowledged that land continues to be scarce and increasingly inaccessible to poor farmers. It is a irony that a major source of income for the region, and especially for poor communities, consists of remittances sent home by Central American refugees and mi- grant workers in the United States and Canada. For example, in 1992, remittances to El Salvador were estimated at US\$718 million, making it the nation's major source of foreign earnings (Arriola 1992).

Despite these significant challenges to peace and development, important opportunities are available for assisting those most affected by the violence and resolving the current situation. Action seems particularly promising along the following four dimensions:

\section{Community identity and leadership}

As Basok and Stepputat indicate in their articles in this issue, the refugees have learned much through the processes of exile and return. They have developed a stronger sense of who they are. They have developed their own vocabulary which links "return" to the peace and development process itself. Return is an important step of self-determination which reinforces local leadership and initiative. Through their experiences abroad, returnees have also developed expectations for schooling and health services, and have acquired negotiating skills with state, intergovernmental and nongovernmental organizations.

Table 2. Select Social and Economic Indicators

\begin{tabular}{|c|c|c|c|c|c|c|c|c|}
\hline \multirow{3}{*}{$\begin{array}{l}\text { Central America } \\
\text { Costa Rica }\end{array}$} & \multirow{2}{*}{$\begin{array}{c}\text { GNP/ Cap. } \\
\text { in } \\
\text { \$US. } \\
(1990)^{*}\end{array}$} & \multirow{2}{*}{$\begin{array}{r}\text { Growth } \\
\text { GNP } \\
\text { per capita. } \\
(1965-90)\end{array}$} & \multirow{2}{*}{$\begin{array}{r}\text { External } \\
\text { Debt as } \\
\text { \%of GNP } \\
(1990)\end{array}$} & \multirow{2}{*}{$\begin{array}{l}\text { opulation } \\
\text { in } \\
\text { millions } \\
(1991)^{*}\end{array}$} & \multirow{2}{*}{$\begin{array}{r}\text { Infant } \\
\text { mortality } \\
\text { rate } / 1000 \\
(1990)\end{array}$} & \multirow{2}{*}{$\begin{array}{c}\text { Population } \\
\text { per } \\
\text { doctor } \\
(1984-89)^{*}\end{array}$} & \multicolumn{2}{|c|}{$\begin{array}{c}\text { Percent } \\
\text { Adult illiterate } \\
(1990)\end{array}$} \\
\hline & & & & & & & Female & Male \\
\hline & 1,900 & 1.4 & 70 & 3.1 & 21 & 960 & 7 & 7 \\
\hline Guatemala & 910 & 0.7 & 38 & 9.5 & 62 & 2,180 & 53 & 45 \\
\hline Honduras & 640 & 0.5 & 141 & 5.3 & 64 & 1,510 & 29 & 27 \\
\hline Nicaragua & 420 & -3.3 & 112 & 3.8 & 55 & 1,560 & 27 & 27 \\
\hline El Salvador & 1,000 & -0.4 & 40 & 5.3 & 53 & 2,830 & 30 & 24 \\
\hline \multicolumn{9}{|l|}{ North America } \\
\hline Canada & 20,380 & 2.7 & $\mathrm{n} / \mathrm{av}$. & 27 & 7 & 455 & 5 & 5 \\
\hline Mexico & 2,490 & 2.8 & 42 & 86.3 & 39 & 1240 & 15 & 13 \\
\hline United States & 21,810 & 1.7 & n/av. & 252 & 9 & 419 & 5 & 5 \\
\hline
\end{tabular}

Sources: World Development Report 1992. World Bank, 1993, Tables 1, 24 and 28, Washington, D.C.: World Bank (") Development Report 1993, UNDP, New York: Oxford University Press 
Their desires and capacities now constitute important resources for leadership in peace and development activities at home.

\section{International linkages and solidarity}

The relationship between external "helping" organizations and the refugees has not always been smooth. Helping organizations can at times begin to dictate and take control without consultation (Basok 1993). However, the experience of the last decade or so has led to improved working relationships between the refugees, the communities to which they are returning and external organizations. Leadership has shifted to the refugee community. The external agencies have taken on the role of "accompaniment" in both a literal sense, i.e., ensuring the safety of the returnees by physically accompanying them on their return (see the article by Beth Abbott in this issue), and in the broader sense of providing emergency and short term development assistance consonant with the returnees' plans. These linkages and international solidarity provide additional important resources for peace and development in the region.

\section{International support}

Monitoring of the peace accords by the United Nations is now an important element in rebuilding the region. The UN peacekeeping force in El Salvador, for example, is small but provides an important external vigilance. Moreover, (as indicated by Kowalchuk and North in this issue), internationally financed development projects play an important role in regenerating local communities, even though these projects may be undermined by macro-economic conditions imposed by the same foreign donor nations. More effort needs to be given to creating an economic climate conducive to development and peace by pursuing macroeconomic policies which will assist, not hinder, local initiatives. Continuing international support for both peacekeeping and economic growth with equity will be important for the durability of repatriation and development efforts in Central America.

\section{Refugee policy}

The welcome evidence of emerging peace and repatriation must not.blind us to the fact that the process is uneven. Individuals, families and communities will not all experience the same conditions. While the conditions for return have been created for large numbers of refugees, others find themselves under threat. Some who have returned may be forced to leave again to find security. Others, for particular circumstances in their community, may need to flee for safety even as conditions generally improve. There will be a continuing need to monitor human rights and to address the need for asylum on a case by case basis. Vigilance is required by those in receiving countries to assure that those in need of asylum receive it. A just refugee policy in receiving countries will continue to be an indispensable resource for the long term effort to build peace, security and prosperity in Central America.

The seventy-five bus loads of Guatemalan refugees who began the recent return to that country stand as a clear illustration of the path to the future in the region. By describing their return as a political act, Guatemalan refugees have articulated a key desire of refugees everywhere-to have greater control over their own lives. The self-led return required that international agencies and nongovernmental organizations provide supportive accompaniment and related development assistance. The efforts of international peacekeepers and promises of local development activity supported by international donors provide a greater measure of security and hope to those returning. The knowledge that asylum is available if required helps to build the confidence of those returning. All of these elements must be strengthened to ensure an enduring and just solution to the challenges of peace and development in Central America.

\section{References}

Arriola, Joaquín. 1992. Coyuntura Económica de El Salvador 1992. Unpublished paper. San Salvador: Universidad Catolica Autonoma.

Asociación para el Avance de las Ciencias Sociales en Guatemala. 1992 (AVANCSO). Donde está el futuro: Procesos de reintegración en comunidades de retomados. Guatemala: Infopress Centroamericana.

Basok, Tanya. 1993. Keeping heads above water: Salvadorean refugees in Costa Rica. Montréal: McGill-Queen's University Press.

Carmack, Robert M. (ed.). 1988. Harvest of violence: The Maya Indians and the Guatemalan crisis. Norman: University of Oklahoma Press.

Fernandez, K., Patricia. M. and Garcia, A.M. 1989. "Informalization at the core: Hispanic women, homework, and the advanced capitalist state." In Portes, A. et al (eds.). The informal economy.

Larkin, M.A., Cuny, F.C. and Stein, B.N. (eds.) 1991. Repatriation Under Conflict in Central America. Washington DC: Center for Immigration Policy and Refugee Assistance, Georgetown University.

North, Liisa and CAPA (eds.). 1990. Between war and peace in Central America: Choices for Canada. Toronto: Between the Lines Press.

Ortega, Marvin. 1991. Nicaraguan repatriation to Mosquitia. Washington DC: Centre for Immigration Policy and Refugee Assistance, Georgetown University.

Ortega, Marvin and Acevedo, Pedro. 1991 "Nicaraguan Repatriation from Honduras and Costa Rica." In Larkin et al. (eds.). Repatriation Under Conflict in Central America. Washington DC: Center for Immigration Policy and Refugee Assistance, Georgetown University.

Portes, A. et al (eds.). 1989. The informal economy. Baltimore: John Hopkins University Press.

Simmons, Alan B. 1993. "Latin American migration to Canada: New linkages in the hemispheric migration and refugee flow system." In International Journal XLVIII (Spring).

Torres-Rivas, Edelberto. 1989. Repression and resistance: The struggle for democracy in Central America. Boulder: Westview Press.

U.S. Committee for Refugees. 1993. El Retorno: Guatemala's Risky Repatriation Begins. Washington, DC: USCR.

Weiss Fagen, Patricia. 1993. "Peace in Central America: Transition for the Uprooted." In World Refugee Survey. Washington, DC: USCR.

Weiss Fagen, Patricia and Eldridge, Joseph T. 1991. "El Salvador: Poor and mobilized." In Larkin et al. (eds.). Repatriation under conflict in Central America. Washington DC: Center for Immigration Policy and Refugee Assistance, Georgetown University.

Whittaker, R. 1987. Double standard: The secret history of Canadian immigration. Toronto: Lester and Orpen Dennys. $\square$ 